\title{
CXCL13 is expressed in a subpopulation of neuroendocrine cells in the murine trachea and lung
}

\author{
Wafaa Mahmoud ${ }^{1,2} \cdot$ Alexander Perniss $^{1} \cdot$ Krupali Poharkar $^{1} \cdot$ Aichurek Soultanova $^{1} \cdot$ Uwe Pfeil $^{1} \cdot$ Andreas Hoek $^{3}$. \\ Sudhanshu Bhushan ${ }^{4} \cdot$ Torsten Hain $^{5}$. Ulrich Gärtner ${ }^{1} \cdot$ Wolfgang Kummer $^{1}[$
}

Received: 29 January 2021 / Accepted: 27 October 2021 / Published online: 11 November 2021

(c) The Author(s) 2021

\begin{abstract}
The conducting airways are lined by distinct cell types, comprising basal, secretory, ciliated, and rare cells, including ionocytes, solitary cholinergic chemosensory cells, and solitary and clustered (neuroepithelial bodies) neuroendocrine cells. Airway neuroendocrine cells are in clinical focus since they can give rise to small cell lung cancer. They have been implicated in diverse functions including mechanosensation, chemosensation, and regeneration, and were recently identified as regulators of type 2 immune responses via the release of the neuropeptide calcitonin gene-related peptide (CGRP). We here assessed the expression of the chemokine CXCL13 (B cell attracting chemokine) by these cells by RT-PCR, in silico analysis of publicly available sequencing data sets, immunohistochemistry, and immuno-electron microscopy. We identify a phenotype of neuroendocrine cells in the naïve mouse, producing the chemokine CXCL13 predominantly in solitary neuroendocrine cells of the tracheal epithelium (approx. 70\% $\mathrm{CXCL}^{+} 3^{+}$) and, to a lesser extent, in the solitary neuroendocrine cells and neuroepithelial bodies of the intrapulmonary bronchial epithelium $\left(<10 \% \mathrm{CXCL}^{+} 3^{+}\right)$. In silico analysis of published sequencing data of murine tracheal epithelial cells was consistent with the results obtained by immunohistochemistry as it revealed that neuroendocrine cells are the major source of Cxcl13-mRNA, which was expressed by 68-79\% of neuroendocrine cells. An unbiased scRNA-seq data analysis of overall gene expression did not yield subclusters of neuroendocrine cells. Our observation demonstrates phenotypic heterogeneity of airway neuroendocrine cells and points towards a putative immunoregulatory role of these cells in bronchial-associated lymphoid tissue formation and B cell homeostasis.
\end{abstract}

Keywords Airway epithelium $\cdot$ Neuroendocrine cells $\cdot$ Neuroepithelial bodies $\cdot$ CXCL13 $\cdot$ Innate immunity $\cdot$ BALT

Wafaa Mahmoud and Alexander Perniss contributed equally.

Wolfgang Kummer

wolfgang.kummer@anatomie.med.uni-giessen.de

1 Institute for Anatomy and Cell Biology, German Center for Lung Research, Excellence Cluster Cardio-Pulmonary Institute (CPI), Justus Liebig University Giessen, 35392 Giessen, Germany

2 Department of Anatomy, Faculty of Medicine, Jordan University of Science and Technology, P.O. Box 3030, Irbid 22110, Jordan

3 Institute for Bioinformatics and Systems Biology, Justus Liebig University Giessen, 35392 Giessen, Germany

4 Institute for Anatomy and Cell Biology, Unit of Reproductive Biology, Justus Liebig University Giessen, 35392 Giessen, Germany

5 Institute of Medical Microbiology, German Center for Infection Research, Partner Site Giessen-Marburg-Langen, Justus Liebig University Giessen, 35392 Giessen, Germany

\section{Introduction}

Neuroendocrine cells, cholinergic chemosensory cells, and ionocytes are rare epithelial cell types of the airways (Plasschaert et al. 2018; Montoro et al. 2018). Cholinergic chemosensory cells are sentinels of microbial products initiating protective neural reflexes and local innate immune responses (Krasteva et al. 2011, 2012; Perniss et al. 2020); ionocytes exhibit particularly high expression of the ion channel CFTR (cystic fibrosis transmembrane regulator) and might be involved in the pathogenesis of cystic fibrosis (Montoro et al. 2018; Plasschaert et al. 2018). Neuroendocrine cells raised clinical interest since they can give rise to small cell lung cancer (Hattori et al. 1972; Park et al. 2011). They occur as solitary neuroendocrine cells, dispersed in the epithelium of the conducting lower airways from the trachea down to the bronchioles, and in clusters termed neuroepithelial bodies, located mainly at branching points of 
intrapulmonary airways. Their distinctive structural feature is secretory dense core granules, which accumulate in the basal region of the cell. Secretory products of airway neuroendocrine cells are, with some species-specific variations, different amines, such as serotonin and $\gamma$-aminobutyric acid (GABA), and neuropeptides, such as calcitonin gene-related peptide (CGRP) (Cutz et al. 2013). Neuroepithelial bodies have been implicated with diverse functions including roles as stem cells promoting epithelial regeneration after injury (Ouadah et al. 2019; Reynolds et al. 2000; Song et al. 2012), mechano- (Lembrechts et al. 2012), and hypoxia sensors (Fu et al. 2000; Kazemian et al. 2001). Recent work identified them as crucial regulators of type 2 immune response in the airways. Mutant mice lacking neuroendocrine cells due to a genetic deficiency of the transcription factor Ascll exhibit severely blunted mucosal type 2 response in models of allergic asthma (Sui et al. 2018). In mouse models of allergic airway inflammation, GABA released from neuroepithelial bodies induces goblet cell hyperplasia, and CGRP stimulates group 2 innate lymphoid cells to release IL-5, which in the end recruits eosinophils (Sui et al. 2018).

Immune cell recruitment in allergic airway inflammation is not restricted to eosinophils but also includes B cells and the formation of bronchus-associated lymphoid tissue (BALT) (Chvatchko et al. 1996). The chemokine (C-X-C motif) ligand 13 (CXCL13), also known as B cell-attracting chemokine 1 (BCA-1), is indispensable for this process. CXCL13 attracts B lymphocytes through binding to the $\mathrm{G}$ protein-coupled receptor CXCR5/BLR1, which is highly expressed not only by B cells, but also by a subpopulation of $\mathrm{CD}^{+}$and $\mathrm{CD} 8{ }^{+} \mathrm{T}$ helper cells (Legler and Thelen 2016; Förster et al. 1996, 1994; Vissers et al. 2001; Cyster et al. 2000; Gunn et al. 1998). Within organized lymphoid tissues such as BALT, CXCL13 is predominantly produced by follicular dendritic cells (Fleige et al. 2014; Gunn et al. 1998; Cosgrove et al. 2020). In established allergic airway inflammation, CXCL13 expression is not restricted to these follicular aggregates, but is widely upregulated in the lung, particularly in the airway epithelium (Baay-Guzman et al. 2012). The cellular sources in homeostatic conditions, however, which may participate in the initial steps in these processes before BALT has been formed, are less clear. Some scattered CXCL13-immunoreactive cells have been described in the airway epithelium of non-allergic control mice, but their identity remained undefined (Baay-Guzman et al. 2012).

We here hypothesized that one of the rare epithelial cell types represents this cellular source of CXCL13 in the murine airway epithelium in homeostatic condition, focussing upon neuroendocrine cells. We addressed this question by light and electron microscopic immunohistochemical approaches and in silico analysis of publicly available single cell sequencing data sets.

\section{Materials and methods}

\section{Animals}

Mice were housed under specific pathogen free (SPF) conditions (10 h dark, $14 \mathrm{~h}$ light) with free access to food and water. This study was carried out in accordance with the recommendations of the European Communities Council Directive of 24 November 1986 (86/609/EEC). The protocol was approved by the local authorities, i.e., Regierungspräsidium Giessen, Germany (reference no. 572_M and 571_M). Wild-type C57BL/6Rj mice (Janvier Labs, Le Genest-Saint-Isle, France, Cat\#5751862) $(n=57)$ and transgenic mice ChAT-eGFP (enhanced green fluorescent protein) (B6.Cg-Tg(RP23-268L19-EGFP)2Mik/J, Jackson Laboratory, Bar Harbour, USA, Cat\# JAX:007902) $(n=7)$ at least 12 weeks of age and from both genders were used. Mice were killed by inhalation of an overdose of $5 \%$ isoflurane (Abbott, Wiesbaden, Germany) and exsanguination through abdominal blood vessels.

\section{R statement}

In this study, more than 100 tissue specimens were collected, investigated, and analyzed. In order to adhere to the $3 \mathrm{R}$ principle (reduction, replacement, and refinement) in animal experiment principle (Russell and Burch 1992), the number of animals used for this study was kept to a minimum by taking multiple organs (urethra, trachea, thymus, gall bladder, and lung, also used for other projects) from the same animal and by taking specimens from animals that have been sacrificed for other purposes.

\section{Tissue preparation}

For whole mount staining and qualitative RT-PCR, the trachea was removed and opened by cutting the trachealis muscle longitudinally to expose the lining epithelium. The trachea was then pinned on a piece of wax to align the epithelial layer approximately in the same plane. Then, the samples were either used for RT-PCR $(n=7)$ as described later or for whole mount immunostaining $(n=19)$. Samples subjected to whole mount staining were fixed overnight by immersion in Zamboni's fixative, composed of $2 \%$ formaldehyde (Carl Roth) and 15\% picric acid (Merck, Darmstadt, Germany), and then washed in $0.1 \mathrm{M}$ phosphate buffer.

Trachea, lung, and spleen processed for sectioning were dissected either freshly or after transcardiac perfusion with Zamboni solution, after initial perfusion with a rinsing solution containing heparin ( $2 \mathrm{ml} / 1 ; 10,000 \mathrm{U}$; Ratiopharm, Ulm, Germany) and procaine hydrochloride (5 g/l; Merck), $\mathrm{pH}$ 
7.4. Subsequently, all tissues were immersed in Zamboni's fixative overnight at $4{ }^{\circ} \mathrm{C}$, washed in $0.1 \mathrm{M}$ phosphate buffer, and, if processed for cryosectioning, stored overnight in $18 \%$ sucrose in the same buffer (Merck). Afterward, specimens were embedded in an OCT cryostat sectioning medium (Sakura Finetek, Staufen, Germany) and stored at $-20{ }^{\circ} \mathrm{C}$ until further processing. Samples of three animals were routinely embedded in paraffin after immersion fixation and buffer wash.

\section{Precision-cut lung slices}

Lungs were taken from 8 to 12-week-old female C57BL/6Rj mice $(n>5)$. Animals were sacrificed as described above, and the airways were filled via the cannulated trachea with 1.5\% low melting agarose (Bio-Rad Medical Diagnostics, Dreieich, Germany) dissolved in HEPES-Ringer buffer (4-(2-hydroxyethyl)-1-piperazineethanesulfonic acid $(10 \mathrm{mM}), \mathrm{KCl}(5.6 \mathrm{mM}), \mathrm{NaCl}(140 \mathrm{mM}), \mathrm{MgCl}_{2}(1 \mathrm{mM})$, $\mathrm{CaCl}_{2}(2.2 \mathrm{mM})$, glucose $(10 \mathrm{mM})$ ). Lungs were removed and transferred to ice-cold HEPES-Ringer buffer to solidify the agarose. The lung lobes were cut into 350- $\mu \mathrm{m}$-thick slices using a vibratome (VT10000S, Leica, Wetzlar, Germany). Slices were incubated in HEPES-Ringer buffer supplemented with penicillin ( $100 \mathrm{U} / \mathrm{ml}$, PAA, Etobicoke, Canada) and streptomycin $(0.1 \mathrm{mg} / \mathrm{ml}, \mathrm{PAA})$ for at least $1.5 \mathrm{~h}$ at $37^{\circ} \mathrm{C}$ to remove the agarose followed by fixation with Zamboni's fixative overnight and subsequent immunostaining.

\section{Immunohistochemistry of tracheal whole mounts and precision-cut lung slices}

Tracheal whole mount preparations and precision-cut lung slices were permeabilized with $0.3 \%$ Triton X-100 in PBS (0.005 M phosphate buffer with $0.08 \mathrm{M} \mathrm{NaCl}, \mathrm{pH} 7.4)$ for $2 \mathrm{~h}$; then, non-specific binding sites were saturated by incubation with blocking solution (4\% normal horse serum and $1 \%$ bovine serum albumin) for $2 \mathrm{~h}$. Primary antibodies (Supplementary table 1) were applied overnight at room temperature. Samples were then incubated for $2 \mathrm{~h}$ with blocking solution and incubated overnight with secondary antibodies (Supplementary table 2). Nuclei were labeled with DAPI ( $1 \mu \mathrm{g} / \mathrm{ml}$; D9542, Sigma-Aldrich, St. Louis, USA); samples were post-fixed in $4 \%$ formaldehyde (Carl Roth, Karlsruhe, Germany) for 10 min and coverslipped in Mowiol (Merck). Whole mounts were evaluated using confocal laser scanning microscopes (LSM 710, Zeiss; FLUOVIEW FV3000, Olympus, Tokyo, Japan; TCS SP8 LIGHTNING, Leica) equipped with appropriate filter and laser sets. Whole trachea overview images were created using the LSM 710 (Zeiss); single pictures were stitched manually using Inkscape version 0.92 .4 (https://inkscape.org/de/).

\section{Immunohistochemistry of sections}

For cryosections, $10-\mu \mathrm{m}$-thick sections were cut using a microtome (CM-1900 cryostat; Leica). Sections were incubated for $1 \mathrm{~h}$ with a blocking solution containing $10 \%$ normal horse serum, $0.5 \%$ Tween 20 , and $0.1 \%$ bovine serum albumin. Primary antibodies were applied overnight (see supplementary table 1). After primary antibodies, samples were washed and incubated for $1 \mathrm{~h}$ with secondary antibodies (supplementary table 2). Nuclei were labeled with DAPI. Afterwards, samples were post-fixed in $4 \%$ paraformaldehyde for $10 \mathrm{~min}$ and coverslipped with a drop of carbonatebuffered glycerol ( $\mathrm{pH}$ 8.6). Immunolabelling for lymphocyte markers was conducted on $7-\mu$ m-thick paraffin sections. Sections were deparaffinised, subjected to antigen retrieval by microwave treatment for $10 \mathrm{~min}$ in citrate buffer $(\mathrm{pH} \mathrm{6.0)}$, and then immunolabelled according to the same protocol as cryosections. The specificity of antibodies was validated by (1) omission of primary antibody to control the specificity of the secondary antibody. (2) For CXCL13 primary antibody, a preabsorption control was done on tracheal cryosections and whole mounts using the immunizing antigen (fulllength recombinant CXCL13, 470-BC-025, R\&D Systems; $10 \mu \mathrm{g} / \mathrm{ml}$ overnight at room temperature), followed by the described immunostaining protocol. (3) Tissue sections from spleen were used as a positive control for CXCL13 immunolabeling and for antibodies against lymphocyte markers. Sections were evaluated by epifluorescence microscopy (Axioplan 2, Zeiss, Oberkochen, Germany) or a confocal laser scanning microscope (LSM 710, Zeiss) equipped with appropriate filter and laser sets.

\section{Cell counting}

For quantitative assessment of double- or triple-labeling immunofluorescence in whole mount tracheal preparations (PGP9.5/CXCL13 ( $n=4$ for studying cranio-caudal distribution; $n=5$ for colocalization studies), CGRP/CXCL13 $(n=5)$, or PGP9.5/CXCL13/eGFP (ChAT) $(n=6))$, Z-stack images through the whole thickness of the epithelium were taken with a $25 \times$ water immersion objective lens and a LSM710 confocal laser scanning microscope (Zeiss). In total, 30 image stacks per trachea were obtained by a randomized scheme. The absolute number of immunoreactive cells was quantified manually using ImageJ plug-in cell counter. For each trachea, the total count of single and double positive cells and their percentages and average numbers per $\mathrm{mm}^{2}$ were calculated. To quantify immunoreactive epithelial cells in the bronchi, double-labeling immunofluorescence with antibodies against CGRP and CXCL13 was performed. Longitudinal sections of the whole lung including the trachea were analyzed (5 animals, 3-4 sections each with a distance of at least $50 \mu \mathrm{m}$ from each other). Counting was 
done manually using an Axioplan 2 epifluorescence microscope equipped with a $40 \times$ objective lens, evaluating the entire section plane.

\section{Electron microscopy}

Tracheas were fixed for at least $24 \mathrm{~h}$ in $2 \%$ paraformaldehyde and $1.5 \%$ glutaraldehyde (Merck) in $0.1 \mathrm{M}$ phosphate buffer (pH 7.4). After fixation, specimens were washed in HEPES buffer $0.15 \mathrm{M}$, pH $7.4(5 \times 10 \mathrm{~min})$, osmicated for $2 \mathrm{~h}$ in aqueous $1 \%$ osmium tetroxide (Sigma-Aldrich), washed in distilled water, contrasted in $1 \%$ uranyl acetate (Merck) overnight, and embedded in epon (Agar Scientific, Essex, UK). Ultrathin sections ( $80 \mathrm{~nm}$ ) were cut using an ultramicrotome (Reichert Ultracut E, Leica).

For pre-embedding immuno-electron microscopy, tracheal cryosections of $40-\mu \mathrm{m}$ thickness were used (CM3050 S cryostat; Leica). Floating sections were rinsed in PBS, and unspecific protein binding sites were saturated with $10 \%$ normal porcine serum in 0.005 M PBS for $1 \mathrm{~h}$. Sections were incubated overnight with goat polyclonal antibody against CXCL13 (1:400 AF470, R\&D Systems) or rabbit polyclonal antibody against $\alpha$ CGRP (1:20,000; T-4032, Peninsula Laboratories) followed by incubation for $1 \mathrm{~h}$ with peroxidase-conjugated pig anti-rabbit Ig (1:100; P0217, Dako, Santa Clara, USA) to detect CGRP or with biotinylated secondary donkey anti-goat IgG (1:400; 705-065147, Dianova) to detect CXCL13. In the latter case, sections were further incubated for $1 \mathrm{~h}$ with peroxidase-coupled streptavidin (1:100; 016-030-084, Dianova). Sections were rinsed in PBS, followed by $0.05 \mathrm{M}$ Tris- $\mathrm{HCl}$ buffer $(\mathrm{pH}$ 8.6), and peroxidase activity was visualized using a solution containing $15 \mathrm{mg} / \mathrm{ml}$ nickel ammonium sulfate (Honeywell, NJ, USA) and $0.125 \mathrm{mg} / \mathrm{ml} 3.3$ '-diaminobenzidinehydrochloride (DAB) (Sigma-Aldrich) in $0.05 \mathrm{M}$ Tris-HCl buffer, for 10 min before adding $\mathrm{H}_{2} \mathrm{O}_{2}$ (Fluka) at a final concentration of $0.0023 \%$ for additional $45 \mathrm{~min}$. Sections were washed in Tris- $\mathrm{HCl}$ buffer, osmicated for $30 \mathrm{~min}$ in aqueous $1 \%$ osmium tetroxide (Sigma-Aldrich), and washed in distilled water. Specimens were stained overnight en bloc with $1 \%$ uranyl acetate (Merck), dehydrated, and flat-embedded in epon (Agar Scientific). Regions containing immunolabeled cells were selected by light microscopy (Leica ICC50 W), trimmed, and transferred to blank epon blocks for ultrathin sectioning $(80 \mathrm{~nm})$. To control the specificity of the secondary antibody, samples were also prepared using the same protocol without a primary antibody. To further validate the specificity of the biotinylated secondary antibodies used in combination with the CXCL13 primary antibody, $10-\mu \mathrm{m}$-thick tracheal sections were air-dried for $1 \mathrm{~h}$ and unspecific protein binding sites were saturated with $10 \%$ normal swine serum in PBS $+\mathrm{S}(0.005 \mathrm{M}$ phosphate buffer, with $0.15 \mathrm{M} \mathrm{NaCl}, \mathrm{pH}$ 7.4) for $1 \mathrm{~h}$. Sections were then incubated overnight either with goat polyclonal antibody to CXCL13 (1:400 AF470, R\&D Systems) and rabbit polyclonal antibody to $\alpha$ CGRP (1:20,000; T-4032, Peninsula Laboratories) or with rabbit polyclonal antibody to $\alpha$ CGRP only. The sections were incubated with biotinylated donkey anti-goat IgG (1:400; 705-065-147, Dianova) for $1 \mathrm{~h}$ followed by incubation for $1 \mathrm{~h}$ with Cy3-coupled streptavidin (1:5000; 016-160-084, Dianova) and donkey anti-rabbit Ig Alexa 488 (1:500, A-21206, Invitrogen). Samples were postfixed in $4 \%$ formaldehyde for $10 \mathrm{~min}$ and coverslipped with a drop of carbonate-buffered glycerol ( $\mathrm{pH}$ 8.6) and evaluated by epifluorescence microscopy (Axioplan 2, Zeiss).

Ultrathin sections were analyzed using a transmission electron microscope (EM 902 N, Zeiss, Oberkochen, Germany) equipped with a slow-scan $2 \mathrm{~K}$ CCD camera (TRS, Tröndle, Moorenweis, Germany). For vesicle diameter measurements, immunoreactive cells in all analyzed sections were captured with 20,000 magnification (2 CGRPimmunoreactive cells and 5 CXCL13-immunoreactive cells). Only vesicles with clear borders were considered for measurements (in total 69 and 174 vesicles in CGRP- and CXCL13-immunoreactive cells, respectively). Two central perpendicular axes for each vesicle were measured with ImageJ software.

\section{Flow cytometry}

Flow cytometry analyses were performed as described before (Wang et al. 2021). Nine female adult C57BL/6 J mice were sacrificed and immediately transcardially perfused with a solution containing polyvinylpyrrolidon (Roth, $25 \mathrm{~g} / \mathrm{l}$ ) and procaine hydrochloride $(5 \mathrm{~g} / \mathrm{l})$, followed by perfusion with PBS (Gibco, Darmstadt, Germany). Cranial (cartilage rings 1-3) and caudal (cartilage rings 8-10) ends of the trachea were separately dissected. Samples of three animals were pooled; two independent experiments were performed. Both parts of the trachea were cut into small pieces and digested in RPMI 1640 medium (Gibco) containing collagenase A ( $1 \mathrm{mg} / \mathrm{ml}$, Roche, Munich, Germany) and DNase I (0.05 mg/ $\mathrm{ml}$, Roche) at $37^{\circ} \mathrm{C}$ in a shaking water bath. Digested tissue was passed 4-5 times through a 3-ml syringe attached with a $21 \mathrm{G}$ needle and filtered through a $70-\mu \mathrm{m}$ filter. Cells were centrifuged $\left(350 \times g\right.$ for $5 \mathrm{~min}$ at $\left.4{ }^{\circ} \mathrm{C}\right)$, and red blood cells were lysed by adding red blood cell lysis buffer (Qiagen Germany). The cells were resuspended in FACS buffer (PBS containing $2 \%$ fetal calf serum (Gibco) and $2 \mathrm{mM}$ EDTA (Sigma-Aldrich)), incubated with Fc blocker (1:10 dilution, Miltenyi Biotec, Bergisch Gladbach, Germany) for $10 \mathrm{~min}$, followed by staining with antibodies (Supplementary table 3) for $30 \mathrm{~min}$ at $4{ }^{\circ} \mathrm{C}$. Subsequently, cells were washed and dissolved in FACS buffer. Flow cytometry analysis was performed using a MACSQuant Analyzer 10 flow cytometer (Miltenyi Biotec); data were analyzed with FlowJo (Version 
10.7.; Tree Star, Ashland, USA). Dead cells were excluded by staining with Zombie NIR ${ }^{\mathrm{TM}}$ Fixable Viability dye (dilution 1:1000, BioLegend, catalogue \#423105).

\section{Reverse transcription PCR and quantitative PCR (RT-PCR, RT-qPCR)}

For qualitative analyses, the tracheal epithelial layer of adult C57BL/6 J mice $(n=7)$ was abraded using cotton swabs soaked with RLT buffer (Qiagen, Hilden, Germany) supplemented with $1 \% \beta$-mercaptoethanol (Sigma). Total RNA from abraded tracheal epithelium was isolated by using the RNeasy Mini kit (Qiagen, Hilden, Germany) according to the manufacturer's instructions. For cDNA synthesis, $8 \mu \mathrm{l}$ RNA was incubated with $1 \mu \mathrm{l} 10 \times$ DNase reaction buffer and $1 \mu \mathrm{l}$ DNase $\left(1 \mathrm{U} / \mu \mathrm{l}\right.$; Invitrogen) for $15 \mathrm{~min}$ at $25^{\circ} \mathrm{C}$ to degrade contaminating DNA. To each sample, $1 \mu \mathrm{l}$ of EDTA $(25 \mathrm{mM})$ was added. After 10 -min incubation at $65^{\circ} \mathrm{C}$, samples were rapidly cooled for $2 \mathrm{~min}$ and $9 \mu \mathrm{l}$ reaction mixture of $1 \mu \mathrm{l}$ oligo-dT $(50 \mu \mathrm{M}), 1 \mu \mathrm{l}$ dNTPs $(10 \mathrm{mM}), 1 \mu \mathrm{l}$ Superscript RNase H-RT (200 U/ $\mu \mathrm{l}), 4 \mu 15 \times$ first-strand buffer, and $2 \mu \mathrm{l}$ dithiothreitol $(0.1 \mathrm{M})$ was added to each sample. All reagents were from Invitrogen, except dNTPs which were from Qiagen. PCR was performed with cDNA samples using primers (specified below) for CGRP, CXCL13, and $\beta$-actin (housekeeping gene). The following protocol was used: $1 \mu \mathrm{l}$ cDNA as template, $2 \mu \mathrm{MgCl}_{2}(25 \mathrm{mM}), 2.5 \mu \mathrm{l}$ $10 \times$ PCR buffer II, $0.75 \mu \mathrm{l}$ dNTPs $(10 \mathrm{mM}), 0.75 \mu \mathrm{l}$ of each primer $(20 \mathrm{pM}), 0.25 \mu \mathrm{l}$ AmpliTaq Gold DNA polymerase (5 U/ $\mu 1$; all reagents were purchased from Thermo Fisher), and $17.75 \mu \mathrm{H}_{2} \mathrm{O}$. PCR was conducted with the following temperature and time profile: $95{ }^{\circ} \mathrm{C}$ for $12 \mathrm{~min}$ for initial denaturation, followed by 39 cycles at $95^{\circ} \mathrm{C}$ for $20 \mathrm{~s}, 60^{\circ} \mathrm{C}$ for $20 \mathrm{~s}$, and $72{ }^{\circ} \mathrm{C}$ for $20 \mathrm{~s}$ and a final extension at $72{ }^{\circ} \mathrm{C}$ for 7 min. $\beta$-Actin was used as an efficacy control for PCR, and omission of the reverse transcriptase during cDNA synthesis served as a negative control. Water negative controls were also processed with each reaction to test for the absence of genomic DNA contamination. The PCR products were subjected to electrophoresis in ethidium bromide-containing $2 \%$ agarose gels. A 100-bp DNA ladder (Invitrogen) was run as a marker, and bands were detected by UV light. Primer pairs used: CGRP fwd: atgcagatgaaagccaggga, rev: aagttgtccttcaccacacc, product length $158 \mathrm{bp}$, GeneBank accession number NM001289444; CXCL13 fwd: aggccacggtattctggaag, rev: agcttggggagttgaagaca, product length $250 \mathrm{bp}$, NM018866; and $\beta$-actin fwd: gtgggaatgggtcagaagg, rev: ggcatacagggacagcaca, product length $300 \mathrm{bp}$, NM007393.

For RT-qPCR, samples from cranial (cartilages 1-3) and caudal (cartilages 8-10) trachea were taken from 6 animals and processed for further analysis. Total RNA was isolated by using the RNeasy Micro kit (Qiagen) according to the manufacturer's instruction. Contaminating DNA was removed by on column digest using the RNase-Free DNase set (Qiagen). Reverse transcription was done as described for RT-PCR. iQ SYBR Green Supermix (Bio-Rad) was used for $\mathrm{qPCR}$ with the following temperature and time profile: $95^{\circ} \mathrm{C}$ for $5 \mathrm{~min}$ for initial denaturation, followed by 40 cycles at $95{ }^{\circ} \mathrm{C}$ for $20 \mathrm{~s}, 60{ }^{\circ} \mathrm{C}$ for $20 \mathrm{~s}$, and $72{ }^{\circ} \mathrm{C}$ for $20 \mathrm{~s}$. $\beta$-Actin served as a housekeeping gene. Samples processed without reverse transcriptions and water controls were included to control for absence of DNA contamination. Gel electrophoresis was done as described for RT-PCR. Primer pairs used: CD22 fwd: gcgctttccagagagtgaca, rev: ccgcttctgtatcaccgagt, product length $112 \mathrm{bp}$, GeneBank accession number NM001043317; CD19 fwd: gaggcacgtgaaggtcattg, rev: gaagaatctcctggcgggg, product length 192 bp, GeneBank accession number NM009844; CD4 fwd: agtagttcaagtggtggecc, rev: gagcccaaggaaacccagaa, product length $172 \mathrm{bp}$, GeneBank accession number NM013488; CD8 fwd: ggacgaagctgactgtggtt, rev: ggtggtaaggctgcatgtca, product length $137 \mathrm{bp}$, GeneBank accession number NM009858. $\beta$-Actin and CXCL13 primers were the same as described for RT-PCR. Relative expression was calculated by $2^{-\Delta \mathrm{Ct}}$, where $\Delta \mathrm{Ct}$ was calculated as the $\mathrm{Ct}$ of the gene of interest minus the $\mathrm{Ct}$ of the housekeeping gene.

\section{In silico analysis of published mRNA sequencing data}

Previously published gene expression data (Plasschaert et al. 2018, data set GSE102580, and Montoro et al. 2018, data set GSE103354) of murine tracheal epithelial cells from uninjured C57B16/J mice were downloaded from SPRING and re-analyzed. Analysis and re-clustering were done using the Seurat R package (version 2.3.4) (Wolock et al. 2019). Principle component analysis (PCA) was done, and UMAP (Uniform Manifold Approximation and Projection) was used for non-linear dimensional reduction (Satija et al. 2015). Cells were represented in a two-dimensional UMAP plot, and clusters were identified and annotated based on the composition of typical marker genes. From data set GSE102580, heat maps were created using ggplots function heatmap. 2 in R package (https://cran.r-project.org/). Sequencing analysis was performed by two independent operators resulting in the same outcome. The top 200 most expressed genes in neuroendocrine cells were selected. About 60 of them were differentially expressed (fold change $>1$ ) compared to other cell types. From these $\sim 60$ genes, a heat map was created from $\mathrm{CXCL} 13^{+}$and $\mathrm{CXCL} 13^{-}$neuroendocrine cells. Another analysis was done by analyzing the original data set again using different selection criteria (fold change $>2.5$, average TPM value more than 1 in either CXCL13 positive 
or negative groups or both), and these genes were used to create further heat maps.

\section{Statistical analysis}

Data are presented as individual data points with mean \pm standard error of the mean (SEM). Statistical analyses of data were performed with GraphPad Prism software version 7 (La Jolla, CA, USA). Data were analyzed by nonparametric tests (Mann-Whitney $U$ test) or chi-squared test. Differences were considered statistically significant when $p \leq 0.05$.

\section{Results}

\section{Scattered tracheal epithelial cells express CXCL13}

RT-PCR revealed expression of CXCL13 in the abraded tracheal epithelium (Fig. 1). This approach was sensitive enough to detect mRNAs selectively expressed by rare cell types, such as Calca-mRNA, encoding the precursor of the neuropeptide CGRP, which is restricted to neuroendocrine cells in the tracheal epithelium (Fig. 1).

Immunolabeling localized CXCL13 immunoreactivity to solitary cells in the tracheal epithelium (Fig. 2a-d and Supplementary Fig. 1). The specificity of this labeling was validated by appropriate positive (spleen; Supplementary Fig. 2a) and negative controls. CXCL13-immunoreactive cells were absent both after preabsorption of the primary antibody with the immunizing peptide (full-length recombinant CXCL13 protein; Supplementary Fig. 2b, c, and d) and when the primary antibody was omitted to test for specificity of secondary antibodies (Supplementary Fig. 2a). The density of CXCL13-immunoreactive cells was highest in the intercartilage regions (approximately doubled compared to regions overlying cartilage, Fig. 2e) and decreased by more than $50 \%$ from cranial (larynx) to caudal (bifurcation) (Fig. 2f). Only few cells were visible below the bifurcation region (Fig. 2a, d and Supplementary Fig. 1). Real-time PCR confirmed the cranio-caudal difference, demonstrating threefold higher expression of Cxcll3-mRNA in the cranial 3 than in the caudal 3 tracheal ring segments (Fig. $2 \mathrm{~g}$ ).

$\mathrm{B}$ cells, the major target cells of CXCL13, were observed within both the epithelial layer and the lamina propria (Supplementary Fig. 3a), but at rare occurrence with up to only 3 cells per longitudinal section of the trachea. T cells appeared slightly more frequent, although also being rare (Supplementary Fig. 3a). Flow cytometry also revealed low numbers of lymphocytes in trachea (Supplementary Fig. 3b-d). In contrast to CXCL13, a cranio-caudal difference in B and T cells was neither noted in flow cytometry (Supplementary Fig. 3b-d), nor in relative expression of B cell (CD19, CD22) and T cell markers (CD4, CD8) (Supplementary Fig. 4).

\section{CXCL13 is restricted to neuroendocrine cells in the tracheal epithelium}

Neuroendocrine cells, characterized by immunoreactivity to PGP9.5, showed the same distribution pattern as CXCL13-immunoreactive cells with preferential occurrence overlying ligaments between cartilage rings (Fig. 2e) and marked cranio-caudal gradient (Fig. 2f). Doublelabeling revealed colocalization of immunoreactivities to CXCL13 and CGRP, a peptide of neuroendocrine cells, within the same cell (Fig. 2a-d, Supplementary Fig. 1), but with only limited overlap of immunofluorescence signals at high-resolution confocal microscopy (Fig. 3a). CGRP is also contained in peptidergic sensory nerve fibers ramifying underneath and within the tracheal epithelium (Figs. 2a-d and 3b, Supplementary Fig. 1 and Supplementary Video 1) (Krasteva et al. 2011; Terada et al. 1992;

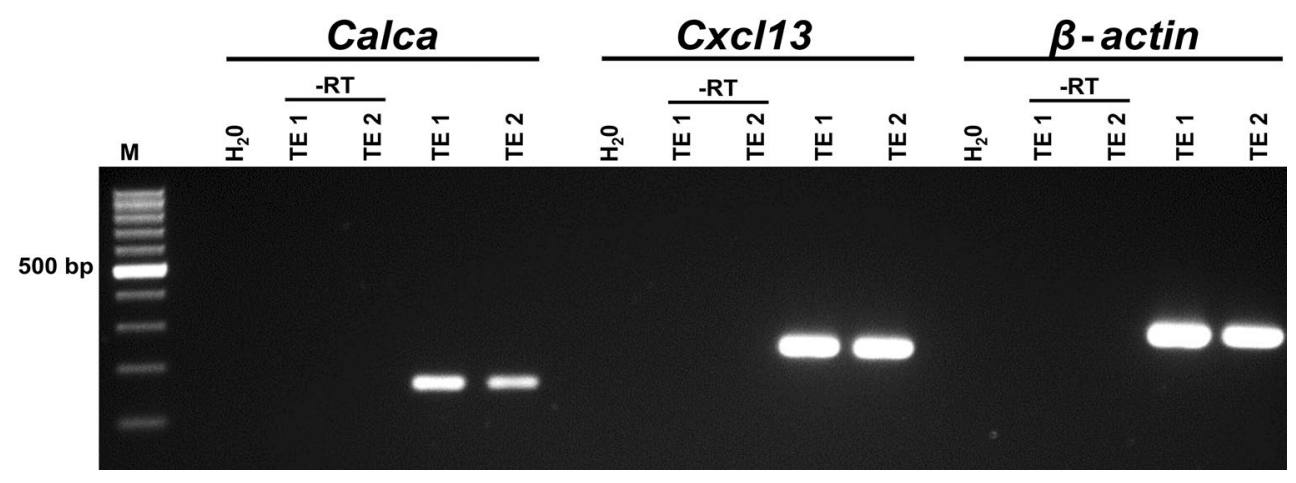

Fig. 1 Cxcl13- and Calca-mRNAs are present in the murine tracheal epithelium. RT-PCR experiments with cDNA obtained from tracheal epithelium of two C57BL/6RJ animals using primers for $\mathrm{Cxcl13}$ (250 bp), Calca (158 bp), and $\beta$-actin (300 bp). Amplicons of Calca,
Cxcl13, and $\beta$-actin are detected in both tracheal epithelium samples $(\mathrm{TE})$. Controls $=$ RNA samples processed without reverse transcriptase (-RT) and water $\left(\mathrm{H}_{2} \mathrm{O}\right)$ without adding cDNA 
a
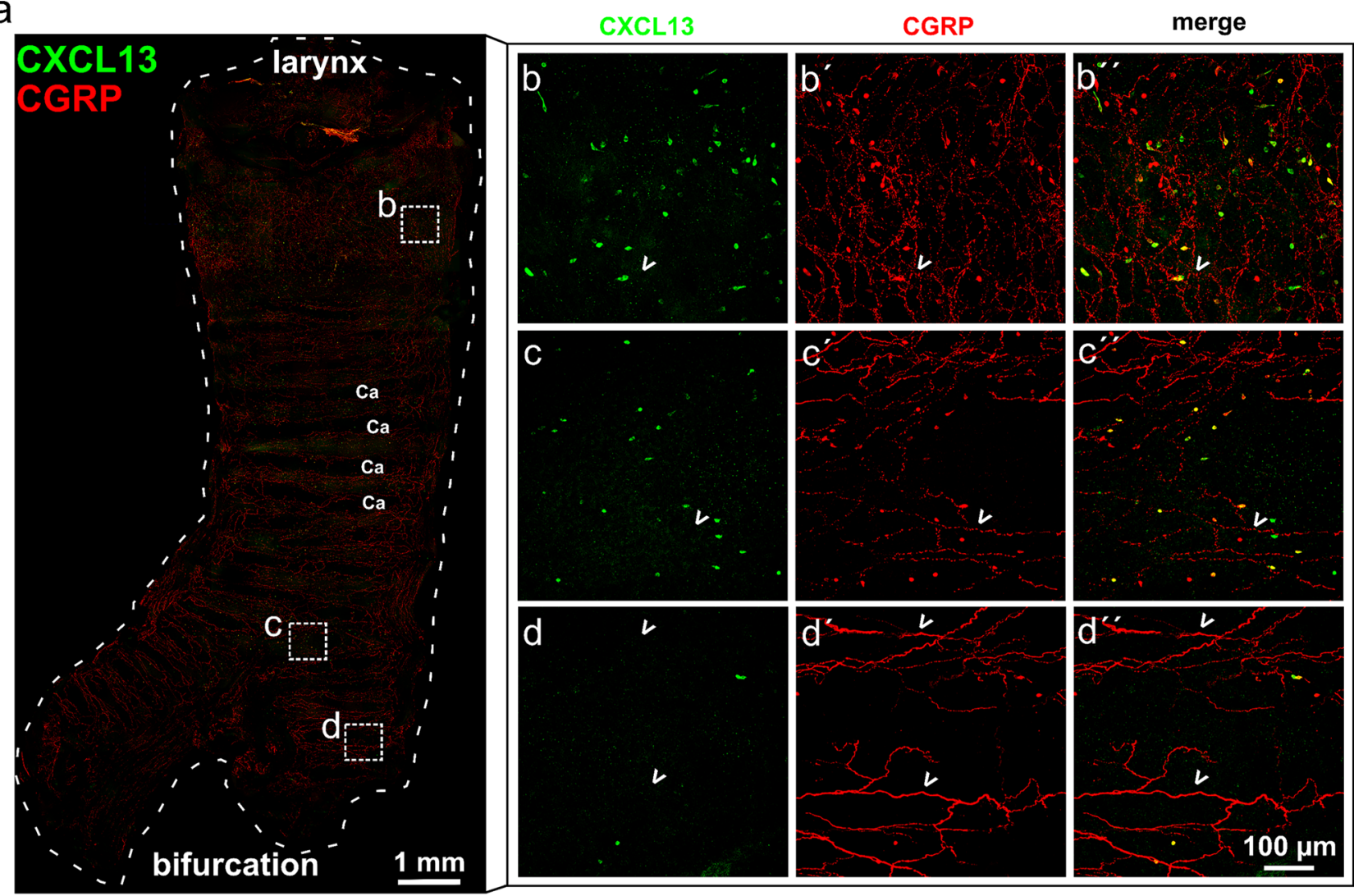

e

f

g
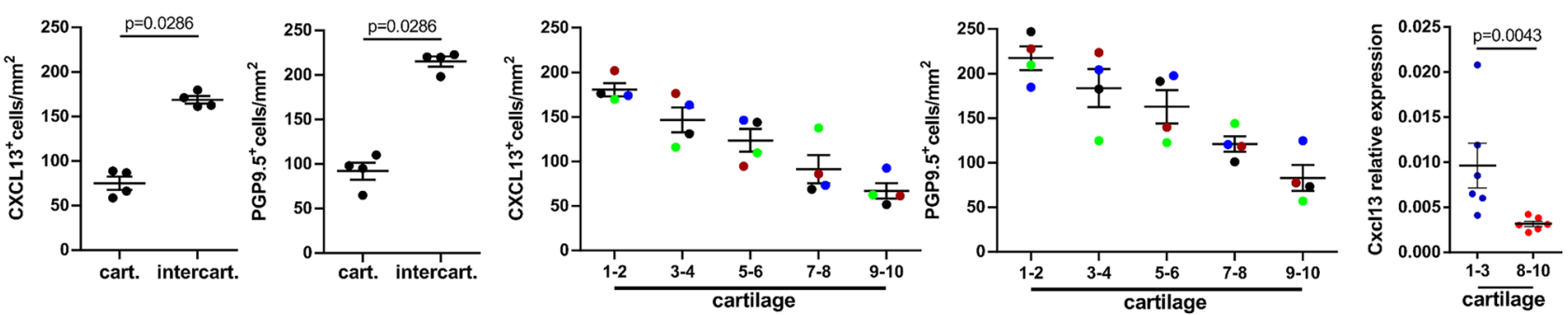

Fig. 2 CXCL13-positive and neuroendocrine cells are unevenly distributed in the trachea. a-d Tracheal whole mount immunohistochemistry, CLSM, with antibodies against CXCL13 (green) and CGRP (red), labeling single neuroendocrine cells and nerve fibers. The density of neuroendocrine (CGRP-positive) cells, CXCL13immunoreactive cells, and nerve fibers is higher between the cartilage rings $(\mathrm{Ca})$. The density of neuroendocrine cells and CXCL13immunoreactive cells decreases from cranial (larynx) (b) to caudal (bifurcation) (d); each channel is individually shown in Supplementary Fig. 1. Numerous CGRP-positive nerve fibers $(<)$ are vis-

Kusindarta et al. 2004). Such nerve fibers made contact to some $\mathrm{CXCL}_{13}{ }^{+} / \mathrm{CGRP}^{+}$epithelial cells, but themselves were CXCL13-negative (Fig. 3b and Supplementary Video 1). Likewise, CXCL13 immunoreactivity colocalized with PGP9.5, another neuroendocrine cell marker, in solitary epithelial cells, while PGP9.5-immunoreactive nerve fibers were CXCL13-negative (Fig. 3c, d). ible throughout the whole trachea. Maximum intensity projection of z-stack of confocal optical sections. e, f Cell densities (mean \pm SEM) quantified on tracheal whole mounts double-labelled for CXCL13 and PGP9.5 (neuroendocrine cell marker). Immunoreactive cells dominate in intercartilage regions (e), and their density continuously declines along the cranio-caudal axis (f). In $\mathbf{f}$, counts include both the area overlying a cartilage and the next intercartilage region; colour coding along the cranio-caudal axis identifies data from the same trachea. g RT-qPCR. Cxcl13 expression is about 3 times higher in tracheal rings $1-3$ compared to rings $8-10$

Pre-embedding immuno-electron microscopy finally validated the neuroendocrine identity of CXCL13-immunoreactive cells. It shall be emphasized that this does not allow to define the precise subcellular localization of CXCL13, since DAB is a diffusible reaction product that can precipitate microns away from the site of enzymatic generation. Ultrastructurally, solitary neuroendocrine cells are characterized by basal 

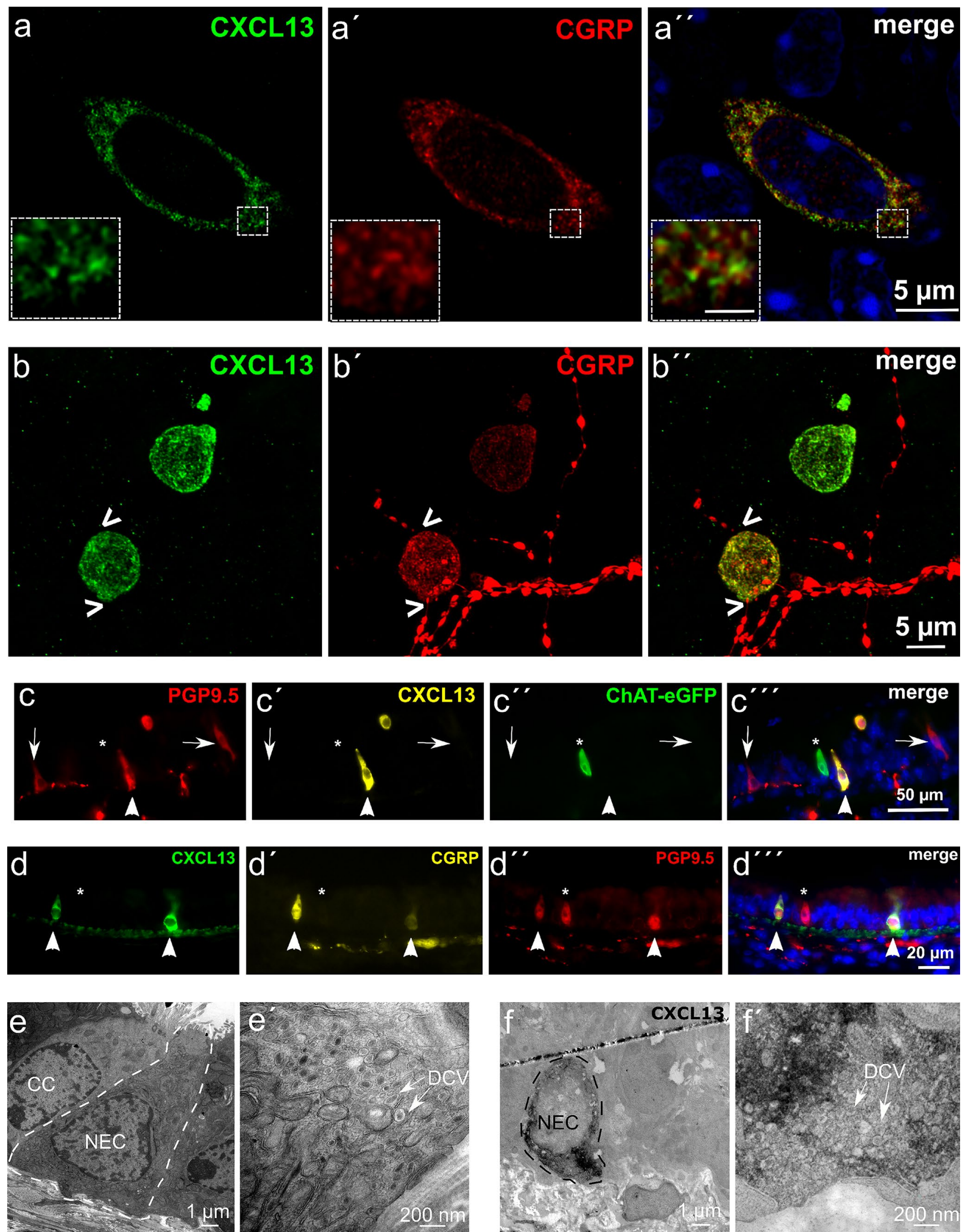
4 Fig. 3 CXCL13 is restricted to neuroendocrine cells in the tracheal epithelium. a, b High-resolution of tracheal whole mount immunohistochemistry, labeling $\mathrm{CXCL}_{1}{ }^{+}$cells in green and $\mathrm{CGRP}^{+}$cells and nerve fibers in red, revealed CXCL13 and CGRP colocalization within the same cell. Inset in a shows the magnified region of the labeled cell with only limited overlap of immunoreactivites (scale bar $1 \mu \mathrm{m})$. Images were acquired using a confocal laser scanning microscope (FLUOVIEW FV3000; Olympus), single confocal optical section. b CXCL13 ${ }^{+}$cell in contact to a $\mathrm{CGRP}^{+}$nerve fiber $(<)$. Maximum intensity projection of z-stack of confocal optical sections. c Immunohistochemistry of a tracheal cryosection from a ChAT-eGFP animal. In the tracheal epithelium, single cells are double-stained with antibodies against PGP9.5 and CXCL13 (arrowhead) or PGP9.5 only (arrow). An eGFP-positive cell (asterisk) is not labeled with antibodies against CXCL13 or PGP9.5. PGP9. $5^{+}$nerve fibers are in contact to PGP9.5 $5^{+}$epithelial cells. d Triple-immunofluorescence of tracheal cryosection shows co-labeling of single epithelial cells for CXCL13 (green), CGRP (yellow), and PGP9.5 (red) (arrowheads). A single PGP9.5-labeled cell with neither CXCL13 nor CGRP immunolabeling is also present (asterisk). e-f Transmission electron microscopy. e Ultrastructure of a tracheal neuroendocrine cell (NEC) with a pyramidal or flask-like shape and a small apical part reaching the lumen with microvilli. $\mathbf{e}^{\prime}$ Higher magnification of the basal part, showing the presence of numerous dense core vesicles (DCV). f Ultrastructural immunohistochemistry with antibodies against CXCL13 shows an immunoreactive cell with the diffuse DAB reaction product. $\mathbf{f}^{\prime}$ Higher magnification of the basal part, showing the presence of numerous DCV

aggregations of small (80-100 $\mathrm{nm}$ in diameter) granules with variable densities (dense core vesicles) (Ericson et al. 1972) (Fig. 3e). Both CGRP- and CXCL13-immunoreactive cells invariably showed these accumulations of dense core vesicles (Fig. 3f, Supplementary Fig. 2e, and controls shown in Supplementary Fig. 2f, g and h). Their average short and long central axis diameters were 75 and $90 \mathrm{~nm}$, respectively, in CGRP-immunoreactive cells (69 vesicles, $n=2$ cells), and 76 and $91 \mathrm{~nm}$ in CXCL13-immunoreactive cells (174 vesicles, $n=5$ cells).

In contrast, solitary cholinergic chemosensory cells were devoid of CXCL13 immunoreactivity, as revealed by doublelabeling experiments utilizing a TRPM5 antibody as a chemosensory cell marker (Supplementary Fig. 5a) and by triplelabeling experiments of tracheas from ChAT-eGFP reporter mice with PGP9.5 and GFP antibodies (Fig. 3c, Supplementary Fig. 5b and c).

\section{Two-thirds of the tracheal neuroendocrine cell population exhibit the $\mathrm{CXCL} 13^{+}$phenotype}

While all CXCL13 ${ }^{+}$cells were PGP9. $5^{+}$, there was a population of PGP9.5 $5^{+}$(neuroendocrine) cells not labeled by the CXCL13 antibody (Fig. 4a). Relative frequencies of immunoreactive phenotypes and their densities in the tracheal epithelium were quantified in whole mount preparations. Doublepositive cells $\left(\mathrm{CXCL13}{ }^{+} / \mathrm{PGP} 9.5^{+}\right)$made up the majority (69\%) of neuroendocrine cells and $\mathrm{CXCL13}{ }^{-} / \mathrm{PGP} .5^{+}$cells accounted for $31 \%$ (Fig. $4 \mathrm{a}^{\prime \prime \prime}$ ). Using CGRP antibody as a marker for neuroendocrine cells in double-labeling experiments revealed highly similar numbers and frequencies (73\% doublepositive, $\left.22 \% \mathrm{CXCL}^{-}{ }^{-} / \mathrm{CGRP}^{+}\right)$, albeit a small fraction $(5 \%)$ of $\mathrm{CXCL}_{13}{ }^{+}$cells without CGRP immunoreactivity appeared in these experiments (Fig. 4b and Supplementary Fig. 6).

These immunohistochemical findings were validated and supplemented with in silico analysis of published sequencing data of murine tracheal epithelial cells (Plasschaert et al. 2018; Montoro et al. 2018). We were able to reproduce the clustering reported by the sequencing laboratories, identifying eight distinct cell clusters, namely basal, secretory, $\mathrm{Krt} 4 / 13^{+}$, ciliated, ionocytes, solitary cholinergic chemosensory (brush/tuft), cycling basal, and solitary neuroendocrine cells in the data set GSE102580 from Plasschaert and coworkers (Fig. 5a), and seven distinct cell clusters, namely basal, club, ciliated, goblet, solitary cholinergic chemosensory (brush/tuft), solitary neuroendocrine cells, and ionocytes in the data set GSE103354 from Montoro and coworkers (Supplementary Fig. 7a). This analysis revealed that neuroendocrine cells are the major source of Cxcl13mRNA in the mouse tracheal epithelium, whereas its expression was negligible (expressed by $1 \%$ of cells or less) in other epithelial cell types. Cxcl13-mRNA was found in $68 \%$ (36/53; data set GSE102580; Fig. 5b) and 79\% (54/68; data set GSE103354; Supplementary Fig. 7b, c), respectively, matching the $69-73 \%$ determined by immunohistochemical double labeling.

Further analysis revealed a panel of $\sim 100$ genes that showed a different expression level (fold change $>2.5$ ) between $\mathrm{Cxcll}^{+}$and $\mathrm{Cxcl13} 3^{-}$cells. While we could not identify a gene known to be involved in CXCL13 signaling pathways, Robol was found among these differentially regulated genes, being upregulated in the $\mathrm{CXCL} 13^{+}$cell population (15/36 versus 4/17 in CXCL13- cells) (Supplementary Fig. 8a and b). Robo expressed by lung neuroendocrine cells is required to cluster into neuroepithelial bodies (Branchfield et al. 2016). Unbiased analysis of both data sets, however, allowed no subclustering of neuroendocrine cells based on distinct gene expression patterns (Supplementary Fig. 7d and 8c). Specifically, we did not find differences between $\mathrm{CXCL}_{13}{ }^{+}$and $\mathrm{CXCL} 13^{-}$neuroendocrine cells with respect to the highest expressed genes, including commonly used neuroendocrine cell marker genes (e.g., Ascll, Uchll, Calca, Chga, Chgb), analyzed in data set GSE102580 (Fig. 5c).

\section{CXCL13 is less expressed in broncho-pulmonary solitary and clustered neuroendocrine cells}

In intrapulmonary airways, the vast majority $(95.3 \%$; 1475/1548 cells from 5 animals) of all $\mathrm{CGRP}^{+}$cells was aggregated to neuroepithelial bodies and only $4.7 \%$ of all $\mathrm{CGRP}^{+}$cells were solitary neuroendocrine cells $(73 / 1548)$ (Supplementary Fig. 9a). 
Fig. 4 CXCL13 is expressed in two-thirds of the murine tracheal neuroendocrine cells. a, b Immunohistochemistry of tracheal whole mounts and the corresponding quantification of their immunoreactive cells; maximum intensity projections of $\mathrm{z}$-stacks of confocal optical sections. a Immunohistochemistry with antibodies against CXCL13 (a) (green) and PGP9.5 (a') (red), labeling single neuroendocrine cells and nerve fibers. $\mathrm{CXCL}^{+}{ }^{+}$/ PGP9. $5^{+}$cells are indicated by arrowheads; $\mathrm{CXCL}^{-}{ }^{-}$/ PGP9. $5^{+}$cells are indicated by $(<)$. Data points in the scatter plot (a' $\left.\mathbf{a}^{\prime \prime \prime}\right)$ represent mean values of counts in one trachea $(n=5$ tracheas); mean and SEM are indicated. The pie chart shows the percentages of $\mathrm{CXCL}^{+} 3^{+}$ PGP9. $5^{+}$and CXCL13PGP9. $5^{+}$cells $(n=2254$ cells pooled from 5 tracheas). b Immunohistochemistry with antibodies against CXCL13 (b) (green) and CGRP $\left(\mathbf{b}^{\prime}\right)$ (red), labeling single neuroendocrine cells and nerve fibers. $\mathrm{CXCL} 3^{+} / \mathrm{CGRP}^{+}$cells are indicated by arrowheads; $\mathrm{CXCL13}^{-} / \mathrm{CGRP}^{+}$cells are indicated by $(<) ; \mathrm{CXCL13}^{+}$/ CGRP $^{-}$cells are indicated by (*). Data points in the scatter plot $\left(\mathbf{b}^{\prime \prime \prime}\right)$ represent mean values of counts in one trachea $(n=5$ tracheas); mean and SEM are indicated. The pie chart shows the percentages of phenotypes $(n=2650$ cells pooled from 5 tracheas)
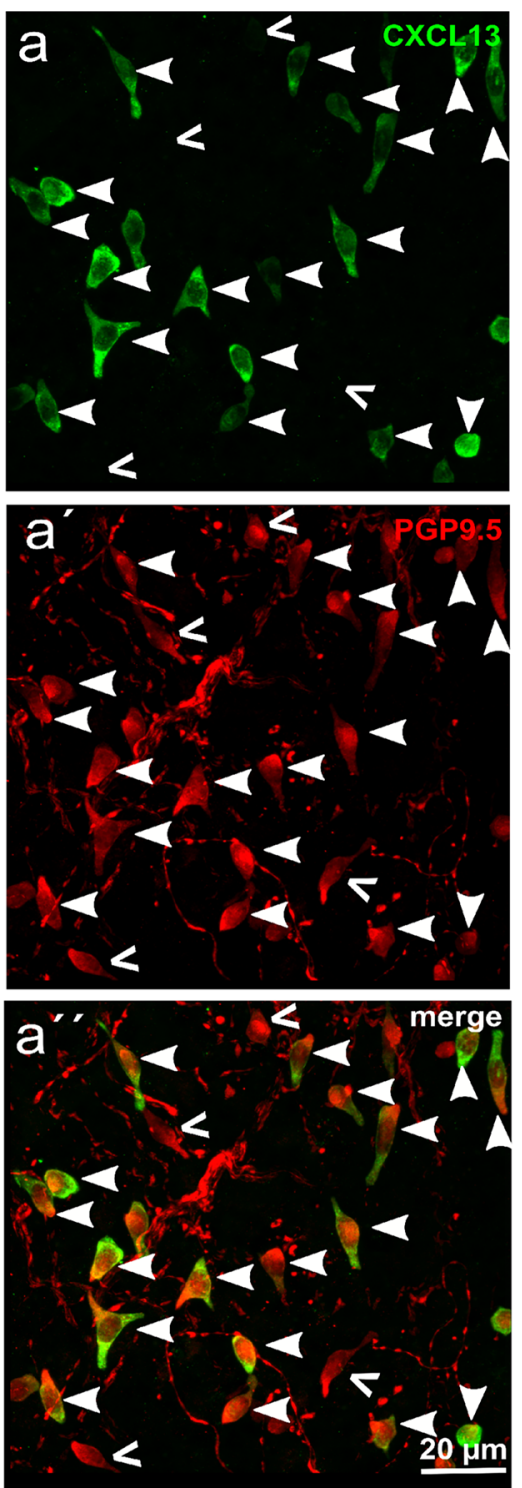

a

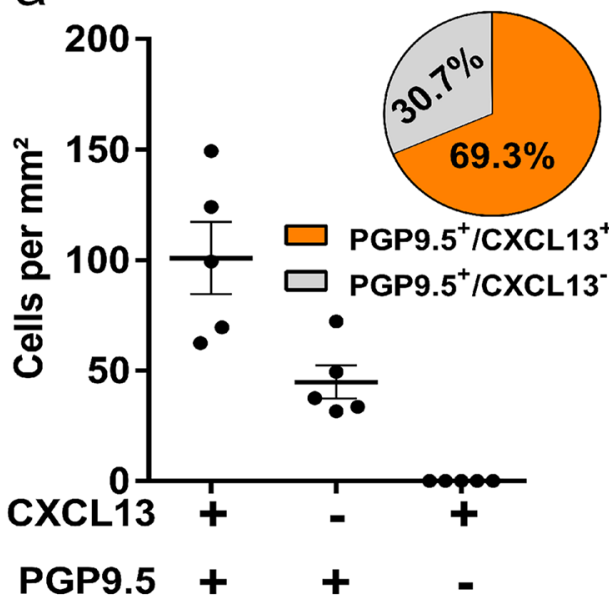

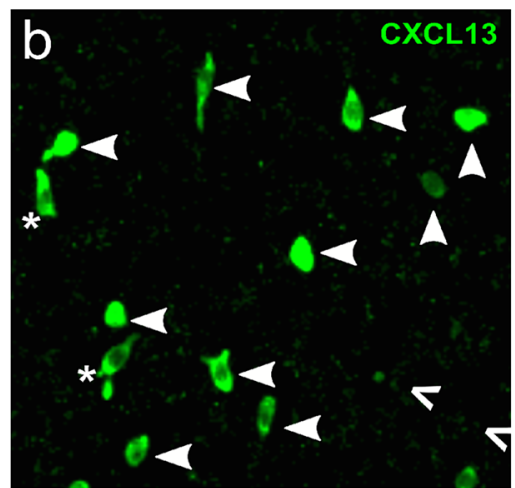
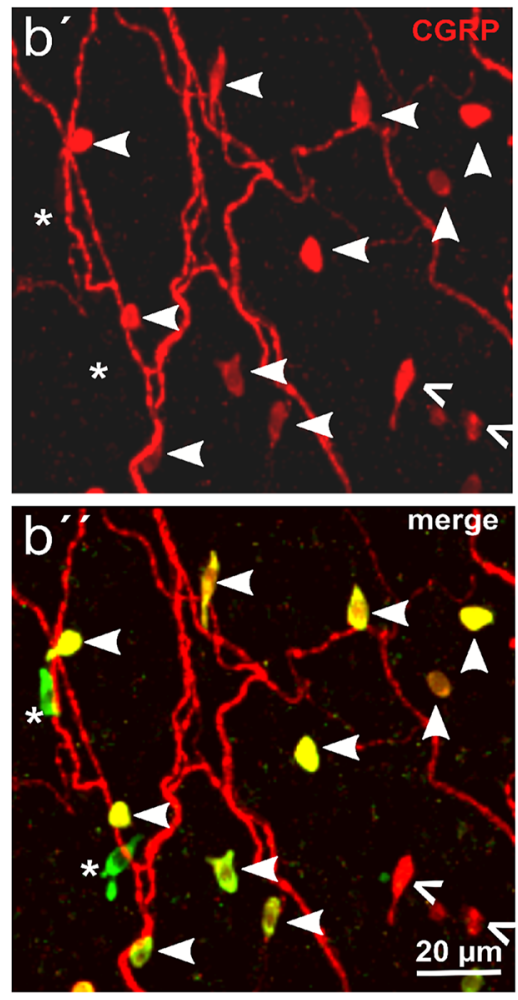

b"'

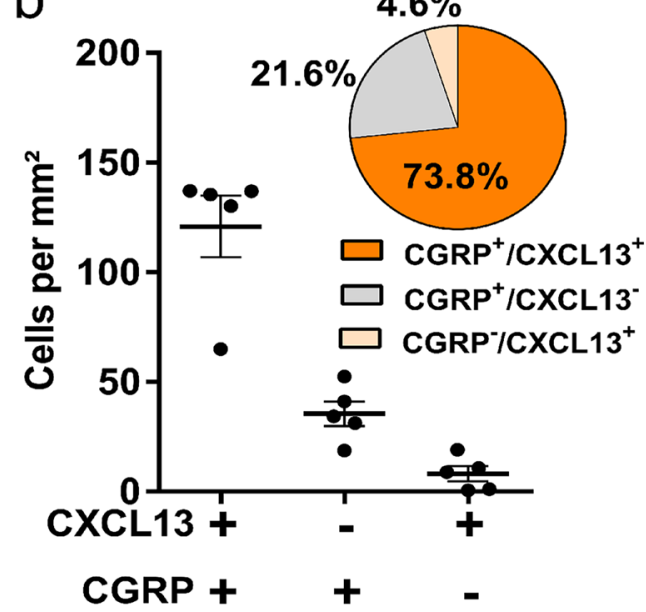


a

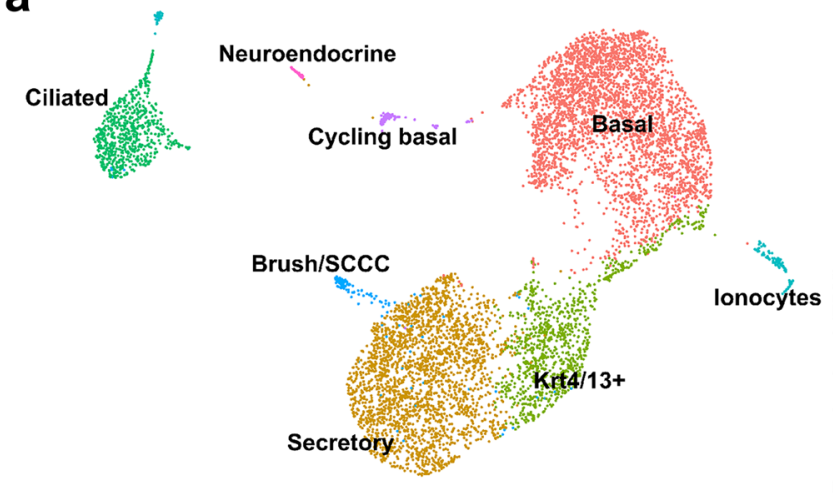

b

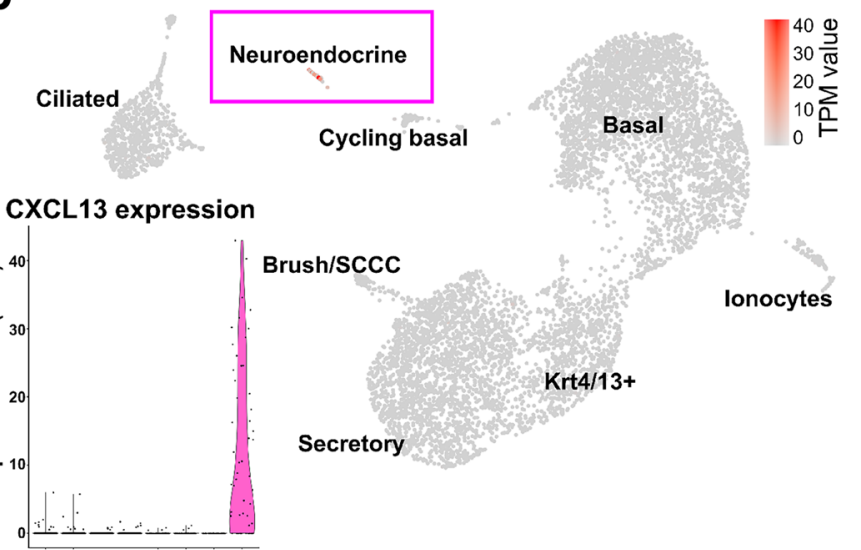

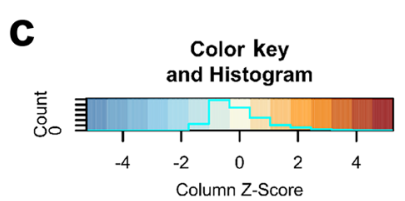

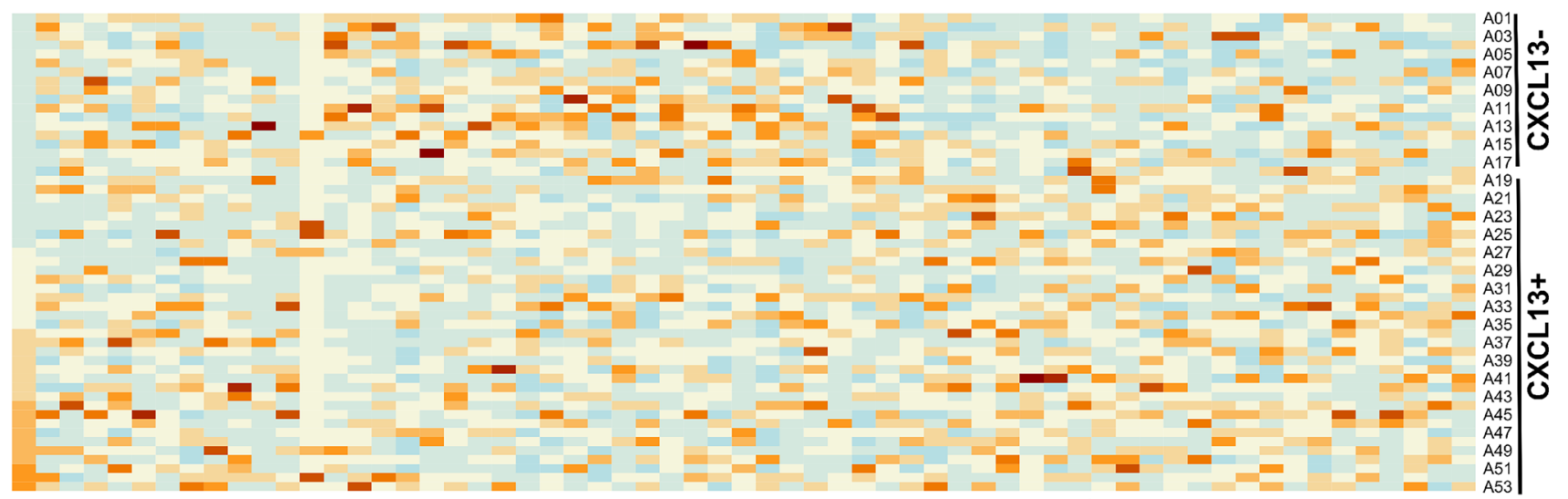

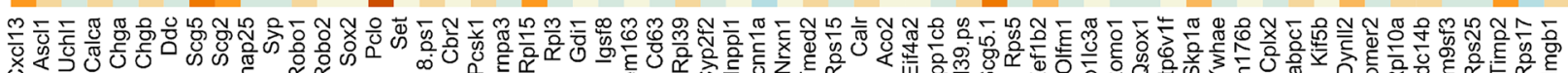

\section{NEC marker genes}

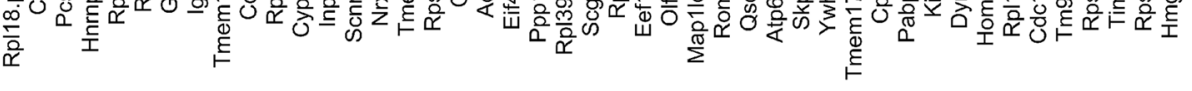

Fig. 5 In silico analysis of single-cell mRNA sequencing data revealed CXCL13 expression predominantly in neuroendocrine cells of the tracheal epithelium. a-c In silico analysis of published sequencing data (GSE102580) of murine tracheal epithelial cells (Plasschaert et al. 2018). a SPRING plot (Uniform Manifold Approximation and Projection, UMAP) shows eight distinct cell clusters, namely basal, secretory, $\mathrm{Krt} 4 / 13^{+}$, ciliated, solitary cholinergic chemosensory (brush/ tuft), cycling basal and solitary neuroendocrine cells, and ionocytes.

In double-labeled tissue sections, CXCL13 immunoreactivity was observed both in solitary and in clustered $\mathrm{CGRP}^{+}$neuroendocrine cells, albeit at much lower frequencies than in the trachea (Fig. 6, Supplementary Figs. 9 and 10). Double-positive cells $\left(\mathrm{CXCL} 3^{+} / \mathrm{CGRP}^{+}\right)$ accounted for $8 \%$ (6/73 cells) of solitary intrapulmonary neuroendocrine cells (Fig. 6d) and for 6\% (82/1475 cells) of CGRP-immunoreactive cells in neuroepithelial bodies (Fig. 6e). $\mathrm{CXCL}^{+} 3^{+} / \mathrm{CGRP}^{-}$epithelial cells were not observed. b SPRING and violin plots showing that Cxcll3-mRNA is predominantly expressed within the neuroendocrine cell cluster. c Heat map shows the most differentially expressed genes (fold change $>1$ ) between $\mathrm{CXCL} 13^{+}$and CXCL13 ${ }^{-}$neuroendocrine cells among the 200 highest expressed genes within the neuroendocrine cell cluster and typical neuroendocrine cell marker genes (e.g., Ascll, Uchll, Calca, Chga, Chgb)

\section{Discussion}

Our data add a homeostatic chemokine, CXCL13, to the portfolio of messengers produced by neuroendocrine cells. As their name reflects, secretory products identified so far included biogenic amines, e.g., serotonin and GABA, which are typically used as neuronal signaling molecules, and peptides also known from neurons or from endocrine cells, e.g., CGRP. A basal accumulation of dense core 
Fig. 6 CXCL13 is less expressed in murine bronchopulmonary solitary and clustered neuroendocrine cells. Immunohistochemistry of lung cryosections with antibodies against CXCL13 (orange) and CGRP (green) and the relative frequencies of immunoreactive phenotypes. a Solitary neuroendocrine cell co-labeled with antibodies against CXCL13 and CGRP. b Solitary neuroendocrine cell only labeled with antibodies against CGRP. c A cluster of neuroendocrine cells (neuroepithelial body) consisting of more than 7 cells, 2 of them are co-labeled with antibodies against CXCL13 and CGRP. d Pie chart shows percentages of $\mathrm{CXCL}_{13}{ }^{+}$/ $\mathrm{CGRP}^{+}$and $\mathrm{CXCL}^{-} 3^{-} \mathrm{CGRP}^{+}{ }_{-}$ immunolabeled cells in solitary neuroendocrine cells ( $n=73$ cells pooled from 5 animals). e Pie chart shows the percentage of $\mathrm{CXCL} 3^{+} / \mathrm{CGRP}^{+}$and CXCL13-/CGRP $^{+}$-

immunolabeled cells in neuroepithelial bodies $(n=1475$ cells pooled from 5 animals)

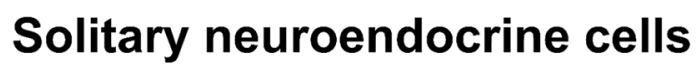

Neuroepithelial body
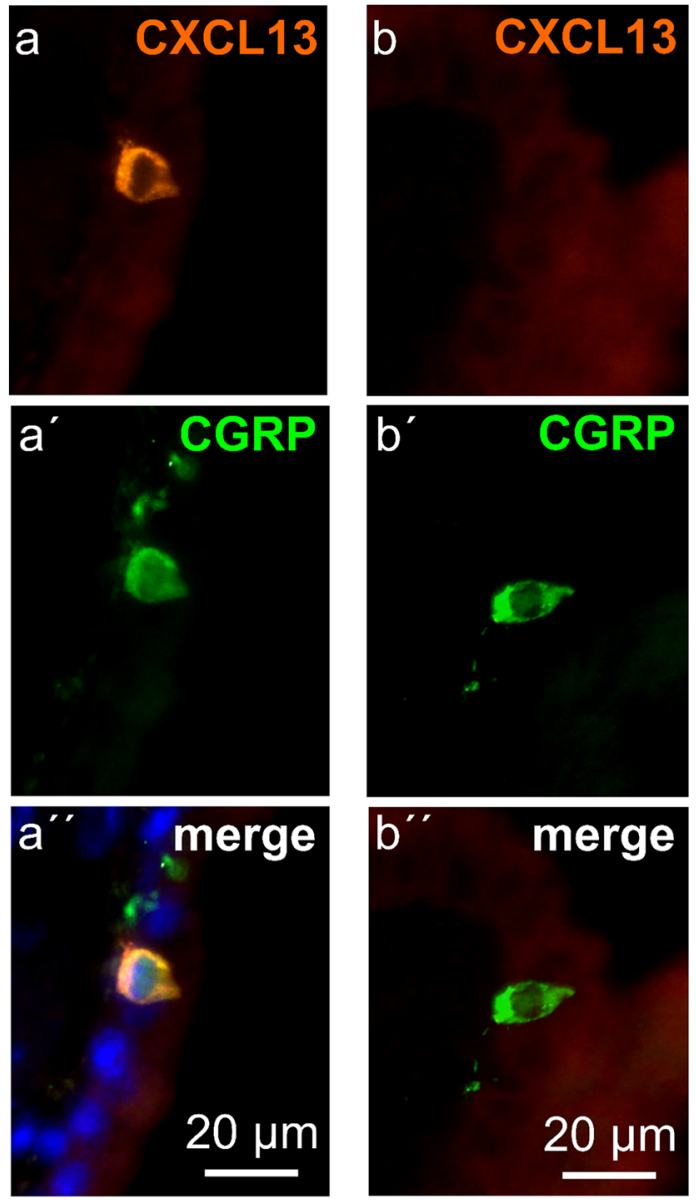

d

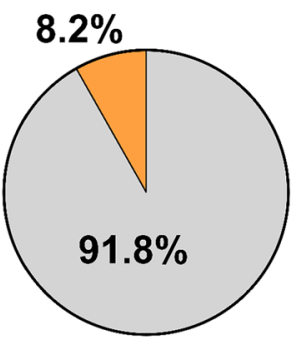

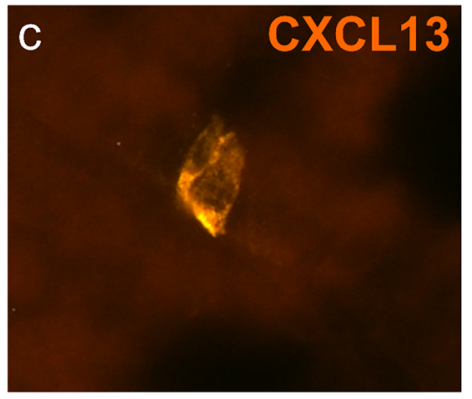
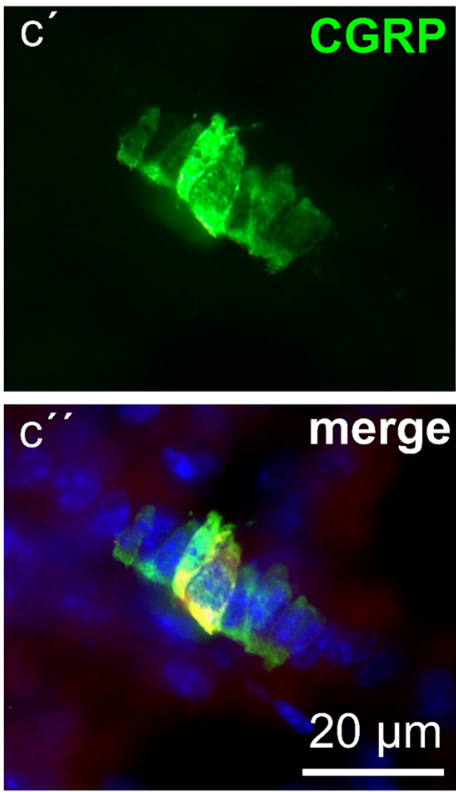

e

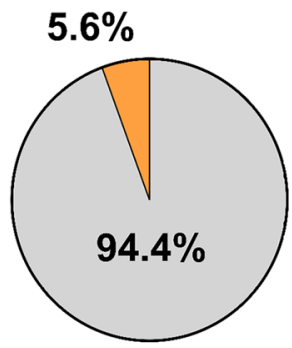

vesicles is the ultrastructural hallmark of airway neuroendocrine cells, and such amines and peptides are often co-stored in and co-released from such vesicles (Fujita et al. 1988). The limited overlap of CXCL13 and CGRP immunoreactivities which we noted in confocal microscopy, however, may result from an independent secretory pathway for CXCL13, matching their anticipated mode of function. CGRP is a pre-formed mediator released by exocytosis of the storage vesicles upon acute stimulation, e.g., exposure of human airway neuroendocrine cells to volatile chemicals (Gu et al. 2014). Chemokines are preferentially released through constitutive secretory pathways (Morales-Tirado et al. 2004; Reikvam et al. 2019). The specific secretory pathways of CXCL13 yet have not been investigated, but its homeostatic role in governing B cell migration through tissues is compatible with a constitutive mode of secretion. On the other hand, the marked cranio-caudal gradient in numbers of CXCL13 expressing tracheal neuroendocrine cells was not paralleled with a similar uneven distribution of B cells along the craniocaudal axis. Thus, pure numbers of CXCL13 expressing cells alone are not sufficient to induce regional inhomogeneity in B cell distribution in the trachea under steadystate conditions.

Double-labeling experiments with antibodies against two different neuroendocrine cell markers and in silico analysis 
of available single cell RNA sequencing data very consistently revealed that approximately two-thirds of tracheal neuroendocrine cells express CXCL13, while a third is CXCL13-negative at a given time point. Despite this heterogeneity, however, an unbiased scRNA-seq analysis of overall gene expression data did not yield subclusters of neuroendocrine cells, and expression of the most characteristic and defining genes of neuroendocrine cells was not different between $\mathrm{CXCL} 13^{+}$and $\mathrm{CXCL} 13^{-}$cells. Hence, we consider CXCL13 ${ }^{+}$and $\mathrm{CXCL} 13^{-}$as phenotypes of one cell type rather than proposing to subdivide neuroendocrine cells into two distinct entities defined by the expression or not of CXCL13.

This concept implies plasticity of CXCL13 expression in neuroendocrine cells, as it is also a characteristic feature of several other cell types. CXCL13 expression can be induced in various airway epithelial cells, pneumocytes, macrophages, and pulmonary reticular cells/fibroblasts in diverse inflammatory conditions such as allergic airway inflammation, environmental pollutant-induced lung cancer, and bacterial and viral infection (Baay-Guzman et al. 2012; Wang et al. 2015; Bracke et al. 2013; Denton et al. 2019; Frija-Masson et al. 2017). In contrast to neuroendocrine cells, however, there is no or only negligible steady state or homeostatic expression of CXCL13 in these cells. Notably, the raw single-cell RNA sequencing data we analyzed were generated in entirely independent laboratories (Montoro et al. 2018; Plasschaert et al. 2018), showing that baseline expression of CXCL13 in tracheal neuroendocrine cells does not reflect an inflammatory condition that may have occurred unperceived in one particular animal house. Known inducers of CXCL13 expression in non-lymphoid tissue under inflammatory settings include type I interferon, IL-1, IL-17, IL-22, and tumor necrosis factor $\alpha$ (Frija-Masson et al. 2017; Kuroda et al. 2016; Neyt et al. 2016; Barone et al. 2015; Bénézech et al. 2015; Rangel-Moreno et al. 2011). The driver of CXCL13 expression in tracheal neuroendocrine cells under baseline conditions remains to be determined.

In contrast to the trachea, CXCL13 expression occurred in only less than $10 \%$ of broncho-pulmonary neuroendocrine cells. During development, pulmonary neuroendocrine cells differentiate as solitary cells, presumably from basal cells, and then aggregate to neuroepithelial bodies through directed migration within the epithelial cell layer (Kuo and Krasnow 2015; Noguchi et al. 2015). It is unlikely that this clustering induced downregulation of CXCL13 expression compared to the trachea, because solitary pulmonary neuroendocrine cells exhibited equally low frequency of CXCL13 expression. Hence, less bronchopulmonary than tracheal neuroendocrine cells express CXCL13, regardless whether they are aggregated into neuroepithelial bodies or lie solitarily in the epithelium. One possible cause of this difference might be that tracheal and bronchopulmonary neuroendocrine cells represent two distinct entities with profound functional differences. Single-cell sequencing data allowing direct comparison between tracheal and intrapulmonary neuroendocrine cells to address this question are not available yet. Alternatively, neuroendocrine cells of the trachea and intrapulmonary airways basically represent the same cell type at different anatomical locations, but are exposed to different environmental cues driving CXCL13 expression preferentially in the trachea. The particularly high frequency of neuroendocrine cells in the cranial, i.e., sublaryngeal part of the trachea, is suggestive of a sentinel function towards inhaled substances, in line with the observation of the expression of olfactory receptors in cultured human solitary tracheobronchial neuroendocrine cells ( $\mathrm{Gu}$ et al. 2014). Higher exposure to such air-borne stimuli might promote CXCL13 expression in the proximal airways. Yet, this model is not supported by our observation that the relative frequency of CXCL13 $3^{+}$cells changed abruptly from trachea to lung but not gradually along the trachea. Lastly, the cellular microenvironment of tracheal and bronchopulmonary neuroendocrine cells differs, and tracheal neuroendocrine cells might be instructed to express CXCL13 by specific cells of their vicinity. One candidate might be cholinergic chemosensory cells which share two peculiar characteristics of spatial distribution with tracheal neuroendocrine cells: enrichment in epithelial areas between cartilages and a striking cranio-caudal gradient in cell frequency. Direct evidence of cross-talk between these rare cell types, however, has not been reported yet.

Supplementary Information The online version contains supplementary material available at https://doi.org/10.1007/s00441-021-03552-2.

Acknowledgements The expert technical assistance of Anika Seipp, Tamara Papadakis, Gerhard Kripp, Martin Bodenbenner-Türich, and Petra Mermer is gratefully acknowledged. We thank Dr. Ioannis Alexopoulos, Imaging Unit of the Center for Infection and Genomics of the Lung and the Institute for Lung Health, Giessen, for access to the unit and help with the 3D reconstruction shown in Supplementary Video 1.

Author contribution W.M. performed experiments, analyzed the data, and wrote the manuscript. A.P performed experiments, analyzed the data, and wrote the manuscript. K.P. analyzed sequencing data and wrote the manuscript. A.S. performed experiments. U.P. performed experiments. A.H. analyzed sequencing data. B.S. performed experiments and analyzed data. T.H. analyzed sequencing data. U.G. performed experiments. W.K. supervised the work, acquired funding, and wrote the manuscript. All authors reviewed the results and approved the final version of the manuscript.

Funding Open Access funding enabled and organized by Projekt DEAL. This work was supported by the German Research Foundation (DFG SFB-TR84, projects A6 to WK, project B8 to TH; DFG KFO 309 , project $\mathrm{Z} 01$ to $\mathrm{AH}$ and $\mathrm{TH}$; grant $\mathrm{BH} 93 / 1-4$ to $\mathrm{SB}$ ), the German Ministry of Education and Research (BMBF grant FKZ 031 A533 to the BiGi center within the de.NBI network, AH), the German Center for Lung Research (DZL ALI-1.1 to WK), and the Excellence Cluster Cardio-Pulmonary Institute (CPI, EXC 147 to WK). 


\section{Declarations}

Ethical approval Animal welfare: This study was carried out in accordance with the recommendations of the European Communities Council Directive of 24 November 1986 (86/609/EEC). The protocol was approved by the local authorities, i.e., Regierungspräsidium Giessen, Germany (reference nos. 572_M and 571_M).

Informed consent Not applicable.

Conflict of interest The authors declare no competing interests.

Open Access This article is licensed under a Creative Commons Attribution 4.0 International License, which permits use, sharing, adaptation, distribution and reproduction in any medium or format, as long as you give appropriate credit to the original author(s) and the source, provide a link to the Creative Commons licence, and indicate if changes were made. The images or other third party material in this article are included in the article's Creative Commons licence, unless indicated otherwise in a credit line to the material. If material is not included in the article's Creative Commons licence and your intended use is not permitted by statutory regulation or exceeds the permitted use, you will need to obtain permission directly from the copyright holder. To view a copy of this licence, visit http://creativecommons.org/licenses/by/4.0/.

\section{References}

Baay-Guzman GJ, Huerta-Yepez S, Vega MI, Aguilar-Leon D, Campillos M, Blake J, Benes V, Hernandez-Pando R, Teran LM (2012) Role of CXCL13 in asthma: novel therapeutic target. Chest 141:886-894

Barone F, Nayar S, Campos J, Cloake T, Withers DR, Toellner K-M, Zhang Y, Fouser L, Fisher B, Bowman S, Rangel-Moreno J, La Garcia-Hernandez MdL, Randall TD, Lucchesi D, Bombardieri M, Pitzalis C, Luther SA, Buckley CD (2015) IL-22 regulates lymphoid chemokine production and assembly of tertiary lymphoid organs. Proc Natl Acad Sci U S A 112:11024-11029

Bénézech C, Luu N-T, Walker JA, Kruglov AA, Loo Y, Nakamura K, Zhang Y, Nayar S, Jones LH, Flores-Langarica A, McIntosh A, Marshall J, Barone F, Besra G, Miles K, Allen JE, Gray M, Kollias G, Cunningham AF, Withers DR, Toellner KM, Jones ND, Veldhoen M, Nedospasov SA, McKenzie ANJ, Caamaño JH (2015) Inflammation-induced formation of fat-associated lymphoid clusters. Nat Immunol 16:819-828

Bracke KR, Verhamme FM, Seys LJM, Bantsimba-Malanda C, Cunoosamy DM, Herbst R, Hammad H, Lambrecht BN, Joos GF, Brusselle GG (2013) Role of CXCL13 in cigarette smoke-induced lymphoid follicle formation and chronic obstructive pulmonary disease. Am J Respir Crit Care Med 188:343-355

Branchfield K, Nantie L, Verheyden JM, Sui P, Wienhold MD, Sun X (2016) Pulmonary neuroendocrine cells function as airway sensors to control lung immune response. Science 351:707-710'

Chvatchko Y, Kosco-Vilbois MH, Herren S, Lefort J, Bonnefoy JY (1996) Germinal center formation and local immunoglobulin $\mathrm{E}$ (IgE) production in the lung after an airway antigenic challenge. J Exp Med 184:2353-2360

Cosgrove J, Novkovic M, Albrecht S, Pikor NB, Zhou Z, Onder L, Mörbe U, Cupovic J, Miller H, Alden K, Thuery A, O'Toole P, Pinter R, Jarrett S, Taylor E, Venetz D, Heller M, Uguccioni M, Legler DF, Lacey CJ, Coatesworth A, Polak WG, Cupedo T, Manoury B, Thelen M, Stein JV, Wolf M, Leake MC, Timmis J, Ludewig B, Coles MC (2020) B cell zone reticular cell microenvironments shape CXCL13 gradient formation. Nat Commun 11:3677

Cutz E, Pan J, Yeger H, Domnik NJ, Fisher JT (2013) Recent advances and contraversies on the role of pulmonary neuroepithelial bodies as airway sensors. Semin Cell Dev Biol 24:40-50

Cyster JG, Ansel KM, Reif K, Ekland EH, Hyman PL, Tang HL, Luther SA, Ngo VN (2000) Follicular stromal cells and lymphocyte homing to follicles. Immunol Rev 176:181-193

Denton AE, Innocentin S, Carr EJ, Bradford BM, Lafouresse F, Mabbott NA, Mörbe U, Ludewig B, Groom JR, Good-Jacobson KL, Linterman MA (2019) Type I interferon induces CXCL13 to support ectopic germinal center formation. J Exp Med 216:621-637

Ericson LE, Håkanson R, Larson B, Owman C, Sundler F (1972) Fluorescence and electron microscopy of amine-storing enterochromaffin-like cells in tracheal epithelium of mouse. Z Zellforsch Mikrosk Anat 124:532-545

Fleige H, Ravens S, Moschovakis GL, Bölter J, Willenzon S, Sutter G, Häussler S, Kalinke U, Prinz I, Förster R (2014) IL-17-induced CXCL12 recruits B cells and induces follicle formation in BALT in the absence of differentiated FDCs. J Exp Med 211:643-651

Förster R, Emrich T, Kremmer E, Lipp M (1994) Expression of the G-protein-coupled receptor BLR1 defines mature, recirculating B cells and a subset of T-helper memory cells. Blood 84:830-840

Förster R, Mattis AE, Kremmer E, Wolf E, Brem G, Lipp M (1996) A putative chemokine receptor, BLR1, directs B cell migration to defined lymphoid organs and specific anatomic compartments of the spleen. Cell 87:1037-1047

Frija-Masson J, Martin C, Regard L, Lothe MN, Touqui L, Durand A, Lucas B, Damotte D, Alifano M, Fajac I, Burgel PR (2017) Bacteria-driven peribronchial lymphoid neogenesis in bronchiectasis and cystic fibrosis. Eur Respir J 49. https://doi.org/10.1183/ 13993003.01873-2016

Fu XW, Wang D, Nurse CA, Dinauer MC, Cutz E (2000) NADPH oxidase is an $\mathrm{O} 2$ sensor in airway chemoreceptors: evidence from $\mathrm{K}+$ current modulation in wild-type and oxidase-deficient mice. Proc Natl Acad Sci U S A 97:4374-4379

Fujita T, Kanno T, Kobayashi S (1988) The paraneuron. Springer, Tokyo

Gu X, Karp PH, Brody SL, Pierce RA, Welsh MJ, Holtzman MJ, BenShahar Y (2014) Chemosensory functions for pulmonary neuroendocrine cells. Am J Respir Cell Mol Biol 50:637-646

Gunn MD, Ngo VN, Ansel KM, Ekland EH, Cyster JG, Williams LT (1998) A B-cell-homing chemokine made in lymphoid follicles activates Burkitt's lymphoma receptor-1. Nature 391:799-803

Hattori S, Matsuda M, Tateishi R, Nishihara H, Horai T (1972) Oatcell carcinoma of the lung. Clinical and morphological studies in relation to its histogenesis. Cancer 30:1014-1024

Kazemian P, Stephenson R, Yeger H, Cutz E (2001) Respiratory control in neonatal mice with NADPH oxidase deficiency. Respir Physiol 126:89-101

Krasteva G, Canning BJ, Hartmann P, Veres TZ, Papadakis T, Mühlfeld C, Schliecker K, Tallini YN, Braun A, Hackstein H, Baal N, Weihe E, Schütz B, Kotlikoff M, Ibanez-Tallon I, Kummer W (2011) Cholinergic chemosensory cells in the trachea regulate breathing. Proc Natl Acad Sci U S A 108:9478-9483

Krasteva G, Canning BJ, Papadakis T, Kummer W (2012) Cholinergic brush cells in the trachea mediate respiratory responses to quorum sensing molecules. Life Sci 91:992-996

Kuo CS, Krasnow MA (2015) Formation of a neurosensory organ by epithelial cell slithering. Cell 163:394-405

Kuroda E, Ozasa K, Temizoz B, Ohata K, Koo CX, Kanuma T, Kusakabe T, Kobari S, Horie M, Morimoto Y, Nakajima S, Kabashima K, Ziegler SF, Iwakura Y, Ise W, Kurosaki T, Nagatake T, Kunisawa J, Takemura N, Uematsu S, Hayashi M, Aoshi T, Kobiyama K, Coban C, Ishii KJ (2016) Inhaled fine particles induce alveolar macrophage 
death and interleukin- $1 \alpha$ release to promote inducible bronchusassociated lymphoid tissue formation. Immunity 45:1299-1310

Kusindarta DL, Atoji Y, Yamamoto Y (2004) Nerve plexuses in the trachea and extrapulmonary bronchi of the rat. Arch Histol Cytol 67:41-55

Legler DF, Thelen M (2016) Chemokines: chemistry, biochemistry and biological function. Chimia 70:856-859

Lembrechts R, Brouns I, Schnorbusch K, Pintelon I, Timmermans J-P, Adriaensen D (2012) Neuroepithelial bodies as mechanotransducers in the intrapulmonary airway epithelium: involvement of TRPC5. Am J Respir Cell Mol Biol 47:315-323

Montoro DT, Haber AL, Biton M, Vinarsky V, Lin B, Birket SE, Yuan F, Chen S, Leung HM, Villoria J, Rogel N, Burgin G, Tsankov AM, Waghray A, Slyper M, Waldman J, Nguyen L, Dionne D, RozenblattRosen O, Tata PR, Mou H, Shivaraju M, Bihler H, Mense M, Tearney GJ, Rowe SM, Engelhardt JF, Regev A, Rajagopal J (2018) A revised airway epithelial hierarchy includes CFTR-expressing ionocytes. Nature 560:319-324

Morales-Tirado V, Johannson S, Hanson E, Howell A, Zhang J, Siminovitch KA, Fowell DJ (2004) Cutting edge: selective requirement for the Wiskott-Aldrich syndrome protein in cytokine, but not chemokine, secretion by CD4+ T cells. J Immunol 173:726-730

Neyt K, GeurtsvanKessel CH, Deswarte K, Hammad H, Lambrecht BN (2016) Early IL-1 signaling promotes iBALT induction after influenza virus infection. Front Immol 7:312

Noguchi M, Sumiyama K, Morimoto M (2015) Directed Migration of pulmonary neuroendocrine cells toward airway branches organizes the stereotypic location of neuroepithelial bodies. Cell Rep 13:2679-2686

Ouadah Y, Rojas ER, Riordan DP, Capostagno S, Kuo CS, Krasnow MA (2019) Rare pulmonary neuroendocrine cells are stem cells regulated by $\mathrm{Rb}, \mathrm{p} 53$, and Notch. Cell 179:403-416.e23

Park KS, Liang MC, Raiser DM, Zamponi R, Roach RR, Curtis SJ, Walton Z, Schaffer BE, Roake CM, Zmoos A-F, Kriegel C, Wong K-K, Sage J, Kim CF (2011) Characterization of the cell of origin for small cell lung cancer. Cell cycle (Georgetown, Tex.) 10:2806-2815

Perniss A, Liu S, Boonen B, Keshavarz M, Ruppert AL, Timm T, Pfeil U, Soultanova A, Kusumakshi S, Delventhal L, Aydin Ö, Pyrski M, Deckmann K, Hain T, Schmidt N, Ewers C, Günther A, Lochnit G, Chubanov V, Gudermann T, Oberwinkler J, Klein J, Mikoshiba K, Leinders-Zufall T, Offermanns S, Schütz B, Boehm U, Zufall F, Bufe B, Kummer W (2020) Chemosensory cell-derived acetylcholine drives tracheal mucociliary clearance in response to virulenceassociated formyl peptides. Immunity 52:683-699

Plasschaert LW, Žilionis R, Choo-Wing R, Savova V, Knehr J, Roma G, Klein AM, Jaffe AB (2018) A single-cell atlas of the airway epithelium reveals the CFTR-rich pulmonary ionocyte. Nature 560:377-381

Rangel-Moreno J, Carragher DM, La Luz G-H, de, Hwang JY, Kusser K, Hartson L, Kolls JK, Khader SA, Randall TD (2011) The development of inducible bronchus-associated lymphoid tissue depends on IL-17. Nat Immunol 12:639-646
Reikvam H, Aasebø E, Brenner AK, Bartaula-Brevik S, Grønningsæter IS, Forthun RB, Hovland R, Bruserud Ø (2019) High constitutive cytokine release by primary human acute myeloid leukemia cells is associated with a specific intercellular communication phenotype. J Clin Med 8:970

Reynolds SD, Giangreco A, Power JHT, Stripp BR (2000) Neuroepithelial bodies of pulmonary airways serve as a reservoir of progenitor cells capable of epithelial regeneration. Am J Pathol 156:269-278

Russell WMS, Burch RL (1992) The principles of humane experimental technique, Special. Universities Federation for Animal Welfare, Wheathampstead

Satija R, Farrell JA, Gennert D, Schier AF, Regev A (2015) Spatial reconstruction of single-cell gene expression data. Nat Biotechnol 33:495-502

Song H, Yao E, Lin C, Gacayan R, Chen M-H, Chuang P-T (2012) Functional characterization of pulmonary neuroendocrine cells in lung development, injury, and tumorigenesis. Proc Natl Acad Sci U S A 109:17531-17536

Sui P, Wiesner DL, Xu J, Zhang Y, Lee J, van Dyken S, Lashua A, Yu C, Klein BS, Locksley RM, Deutsch G, Sun X (2018) Pulmonary neuroendocrine cells amplify allergic asthma responses. Science 360(6393):eaan8546

Terada M, Iwanaga T, Takahashi-Iwanaga H, Adachi I, Arakawa M, Fujita $\mathrm{T}$ (1992) Calcitonin gene-related peptide (CGRP)-immunoreactive nerves in the tracheal epithelium of rats: an immunohistochemical study by means of whole mount preparations. Arch Histol Cytol 55:219-233

Vissers JLM, Hartgers FC, Lindhout E, Figdor CG, Adema GJ (2001) BLC (CXCL13) is expressed by different dendritic cell subsets in vitro and in vivo. Eur J Immunol 31:1544-1549

Wang GZ, Cheng X, Zhou B, Wen ZS, Huang YC, Chen HB, Li GF, Huang ZL, Zhou YC, Feng L, Wei MM, Qu LW, Cao Y, Zhou GB (2015) The chemokine CXCL13 in lung cancers associated with environmental polycyclic aromatic hydrocarbons pollution. eLife 4:e09419

Wang M, Yang Y, Cansever D, Wang Y, Kantores C, Messiaen S, Moison D, Livera G, Chakarov S, Weinberger T, Stremmel C, Fijak M, Klein B, Pleuger C, Lian Z, Ma W, Liu Q, Klee K, Händler K, Ulas T, Schlitzer A, Schultze JL, Becher B, Greter M, Liu Z, Ginhoux F, Epelman S, Schulz C, Meinhardt A, Bhushan S (2021) Two populations of self-maintaining monocyte-independent macrophages exist in adult epididymis and testis. Proc Natl Acad Sci U S A 118(1):e2013686117

Wolock SL, Lopez R, Klein AM (2019) Scrublet: computational identification of cell doublets in single-cell transcriptomic data. Cell Syst 8:281-291.e9

Publisher's Note Springer Nature remains neutral with regard to jurisdictional claims in published maps and institutional affiliations. 